\title{
Survey of transcripts expressed by the invasive juvenile stage of the liver fluke Fasciola hepatica
}

\author{
Martín Cancela1,2, Natalia Ruétalo³, Nicolás Dell'Oca², Edileuza da Silva', Pablo Smircich², Gabriel Rinaldi2, \\ Leda Roche2, Carlos Carmona ${ }^{4}$, Fernando Alvarez-Valín ${ }^{3}$, Arnaldo Zaha ${ }^{1}$ and José F Tort*2
}

\begin{abstract}
Background: The common liver fluke Fasciola hepatica is the agent of a zoonosis with significant economic consequences in livestock production worldwide, and increasing relevance to human health in developing countries. Although flukicidal drugs are available, re-infection and emerging resistance are demanding new efficient and inexpensive control strategies. Understanding the molecular mechanisms underlying the host-parasite interaction provide relevant clues in this search, while enlightening the physiological adaptations to parasitism. Genomics and transcriptomics are still in their infancy in F. hepatica, with very scarce information available from the invasive newly excysted juveniles (NEJ). Here we provide an initial glimpse to the transcriptomics of the NEJ, the first stage to interact with the mammalian host.
\end{abstract}

Results: We catalogued more than 500 clusters generated from the analysis of F. hepatica juvenile expressed sequence tags (EST), several of them not detected in the adult stage. A set of putative F. hepatica specific transcripts, and a group of sequences conserved exclusively in flatworms were identified. These novel sequences along with a set of parasite transcripts absent in the host genomes are putative new targets for future anti-parasitic drugs or vaccine development. Comparisons of the F. hepatica sequences with other metazoans genomes or EST databases were consistent with the basal positioning of flatworms in the bilaterian phylogeny. Notably, GC content, codon usage and amino acid frequencies are remarkably different in Schistosomes to F. hepatica and other trematodes.

Functional annotation of predicted proteins showed a general representation of diverse biological functions. Besides proteases and antioxidant enzymes expected to participate in the early interaction with the host, various proteins involved in gene expression, protein synthesis, cell signaling and mitochondrial enzymes were identified. Differential expression of secreted protease gene family members between juvenile and adult stages may respond to different needs during host colonization.

Conclusion: The knowledge of the genes expressed by the invasive stage of Fasciola hepatica is a starting point to unravel key aspects of this parasite's biology. The integration of the emerging transcriptomics, and proteomics data and the advent of functional genomics tools in this organism are positioning F. hepatica as an interesting model for trematode biology.

\section{Background}

Fasciola hepatica, the common liver fluke, is recognized as one of the most important parasitic helminths affecting livestock worldwide. Along with the related species $F$. gigantica, F. hepatica is responsible for massive economic

\footnotetext{
* Correspondence: jtort@fmed.edu.uy

2 Departamento de Genética, Facultad de Medicina, Universidad de la

República, UDELAR, Montevideo, Uruguay

+ Contributed equally

Full list of author information is available at the end of the article
}

losses estimated globally at 3.2 bn USD mainly due to reduction in meat, wool and milk output in infected animals, with additional costs derived from liver condemnation and flukicide drugs [1]. During the last decade, its relevance as a zoonotic agent in parts of Latin America and Africa has also emerged, with millions at risk of infection [2,3]. Although effective drugs such as triclabendazole are available, they only provide interim control of the disease, since cattle and sheep are easily reinfected. Moreover, drug resistance against tric- 
labendazole has emerged in Australia and European countries (Ireland, The Netherlands, U.K. and Spain) jeopardizing the long term sustainability of this control strategy [4].

The life cycle of $F$. hepatica is complex and includes a snail and a mammal as intermediate and definitive hosts respectively. Mammals get infected by ingestion of the quiescent larvae (metacercariae) encysted in the vegetation. An interplay of extrinsic signals from the host (digestive enzymes, bile salts, redox potential, $\mathrm{pH}$, temperature among others) and intrinsic factors from the parasite (enzymes and secretions) determine the emergence of a motile larvae [5]. The newly excysted juveniles (NEJ) actively penetrate and transverse the gut wall into the peritoneal cavity within two or three hours. By four or five days post-infection the parasites reach and penetrate the liver, and continue burrowing through the parenchyma for several weeks. Within the major bile ducts the parasites mature and start to release eggs, that can be found in the bile and feces from 8 weeks post-infection [6].

Unlike mature flukes living in the immunologically safe environment of the bile ducts, NEJ are susceptible targets of the immune response. Only $5-10 \%$ of the inoculum in cattle, and $20-25 \%$ in sheep reach maturity in experimental infections, indicating that a great part of the emerged juveniles either fail entering the gut or are killed during the migrating phase $[7,8]$. Vaccination studies also show that effective protection is correlated with reduced liver damage, a signature of previous destruction of the early NEJs. Despite the crucial role of this stage in determining the further success of the infective process, information regarding NEJs, is very limited, mainly due to the scarce availability of material to explore diverse aspects of the parasite biology. Principal roles for stage specific proteases and antioxidant enzymes in the early infection have been demonstrated by us and others [9-12]. Recent proteomic studies were able to reveal important differences among F. hepatica stages [13-15]. However, the identification of the juvenile specific proteins was limited by the paucity of mRNA sequences to match to peptide mass fingerprinting data. While more than 200 protein sequences and 10,000 EST are available from the adult stage, only 22 mRNA sequences from NEJ (mainly corresponding to cathepsin B and L-like cysteine proteinases) were deposited at the Genbank by July 2009. Consequently we decided to conduct a transcriptomic analysis in order to identify the gene repertoire expressed by the invasive stage of $F$. hepatica. Transcriptomic approaches in Schistosoma mansoni and S. japonicum have provided a thorough coverage of the genes expressed by diverse stages $[16,17]$. Furthermore, they have been invaluable tools for the assembly and annotation of the recently released genomes of these important human parasites $[18,19]$, opening new avenues for discovery [20,21]. EST have also been applied successfully to a limited set of other trematodes, namely Echinostoma paraensei [22], Clonorchis sinensis [23-25], Paragonimus westermani [26] and Opisthorchis viverrini [27].

Here we report the analysis of a limited set of NEJ expressed sequence tags, identifying putative stage, species and flatworm specific sequences. This first glimpse of the physiology of the invasive larvae opens new prospects for the understanding of the host-parasite interaction eventually leading to the development of new mechanisms to control fasciolosis, and warrants further analysis using new generation sequencing technologies.

\section{Results and Discussion}

\section{Construction of a newly excysted juvenile F. hepatica CDNA library}

In order to identify the genes expressed during the invasion process of the platyhelminth $F$. hepatica, we constructed a full length enriched cDNA library using a modified protocol based on selective amplification of capped polyadenylated RNA species. Since the starting parasite material was limiting, a modified size fractioning step of the products was introduced in order to improve the yield [28] (Additional File 1). More than four thousand reads were produced and analyzed using the Partigene pipeline [29]. Quality and vector trimming drastically reduced the starting 4319 ESTs to 1684 high quality sequences, mainly due to the presence of multimers of the adapters used in the generation of the libraries (see methods). This setback could be expected considering the minimal amount of starting material, and might be corrected using $5^{\prime}$ blocked adapters in lower concentrations.

The resulting high quality sequences were clustered into 517 different contigs (249 clusters and 268 singletons), $74.6 \%$ of them showing significant similarity ( $E$ value $<1 \mathrm{e}^{-05}$ ) with protein coding genes deposited in public sequence databases, indicating a good representation of cDNAs in this library (Table 1). The most highly abundant EST in juvenile F. hepatica (13.5\% of total reads) corresponds to the large subunit of the mitochondrial ribosomal RNA (LSU rRNA), and was discarded from further analysis. Polyadenylated LSU rRNA has already been described in other platyhelminths [28], and in fact, F. hepatica LSU rRNA has been reported to represent about $10 \%$ of the adult transcripts [30]. Considering that only 22 sequences from NEJ were available in Genbank by July 2009 (15 of them encoding cathepsins), the present report represents a pertinent contribution to the knowledge of the genes expressed by the invasive stage of the common liver fluke. 
Table 1: Overview of $F$. hepatica NEJ ESTs assembly

\begin{tabular}{lr}
\hline NEJ LIBRARY & Partigene \\
\hline EST generated & 4319 \\
Submissable EST & 1684 \\
Contigs & 516 \\
Clusters & 248 \\
Singletons & 268 \\
Mitochondrial LSU RNA & 228 \\
Contigs with Blast hits & 386 \\
Contigs with GO assignments & 174 \\
Contigs with Pfam hits & 179 \\
Average insert size & 347 \\
\hline
\end{tabular}

\section{Comparison and validation of the FhNEJ ESTs with other databases}

In order to establish if the obtained contig sequences correspond to validated transcripts, we compared them to different available databases, including ESTs from the adult $F$. hepatica stage, predicted coding sequences from selected organisms with complete genomes, and transcriptomes of other eukaryotes representing the main lineages in the metazoan diversity (Additional File 2). To compare the data obtained from the juvenile stage to the adult sequences, we retrieved and analyzed using the Partigene pipeline more than 10,000 EST reads from $F$. hepatica adult worms available at the Wellcome Trust Sanger Institute, obtaining 4089 contigs (1879 clusters and 2210 singletons), $58 \%$ of them showing significant blast hits $\left(E\right.$ value $\left.<1 \mathrm{e}^{-05}\right)$ with publicly available databases (Additional File 3). These results are very similar to a recently reported analysis of the same dataset performed using a different pipeline [13].

More than half of the juvenile contigs (55.3\%) were also found in adult ESTs (Figure 1). A set of 91 juvenile contigs (17.6\%), also present in adults, showed no homology to sequences in other databases, suggesting that they might represent Fasciola specific transcripts expressed in diverse stages of the parasite life cycle. On the other hand, there are several juvenile contigs that are absent from the adult database, although represented in other organisms suggesting that they might represent stage specific transcripts (Figure 1). A set of 114 juvenile contigs $(22,1 \%)$ were common to all other organisms searched indicating core eukaryotic functions such as ribosomal proteins and common enzymes. The absence of some of them from the adult dataset might suggest that the representation of the adult libraries is still partial. Interestingly, 64 contigs $(12.4 \%)$ are shared only within flatworms, corresponding

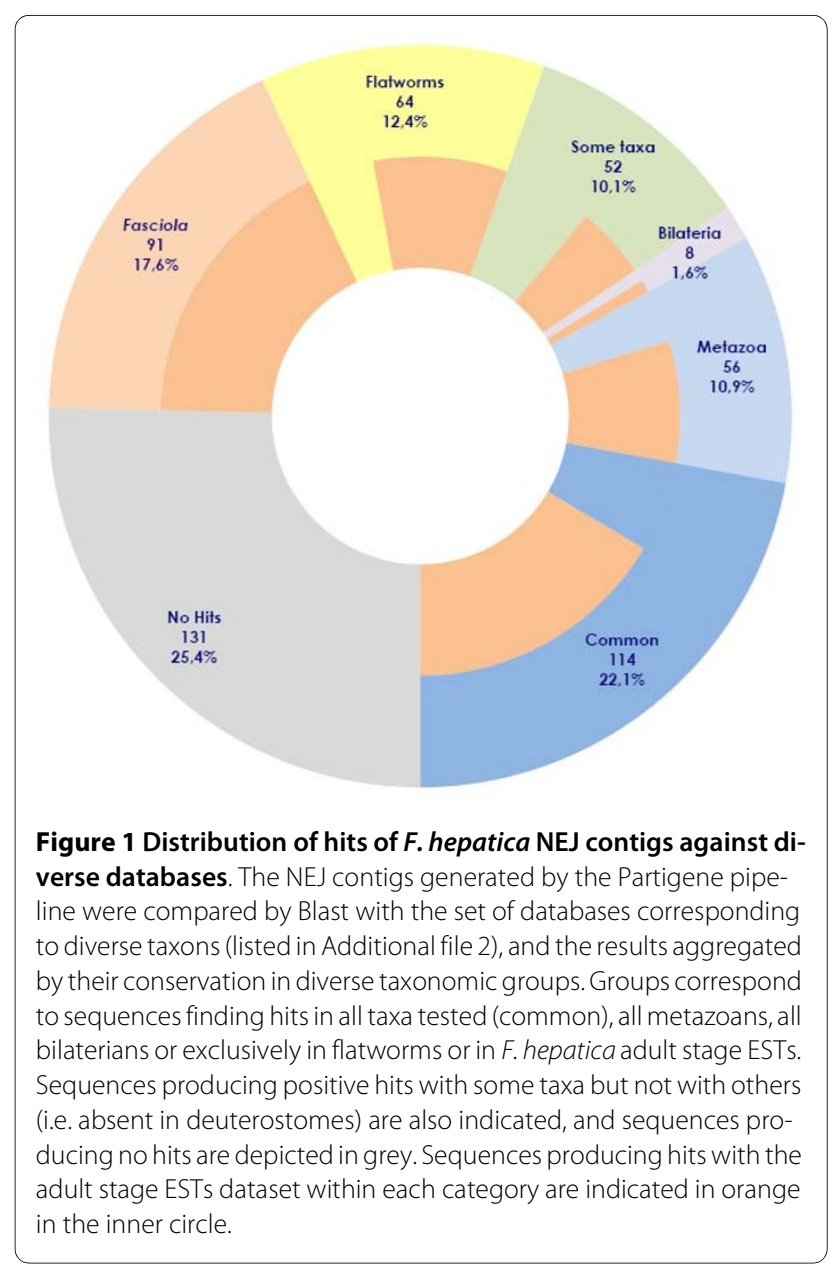

to conserved uncharacterized transcripts that might be relevant to parasitism. Also 56 contigs (10.9\%) are shared only within metazoans and absent in the non metazoan choanoflagellate Monosiga brevicollis, suggesting that they represent metazoan innovations.

To further characterize conservation patterns between different metazoan lineages, we analyzed the distribution of tblastx hits by three-way comparisons using the Simitri program [31]. As expected, the F. hepatica predicted genes are more similar to homologues from other trematodes rather than cestodes and turbellaria, and to all flatworms rather than other protostomes, supporting the monophylectic origin of flatworms (Figure 2A, C). Consistent with the reports from the schistosomes genomes, we detected slightly more shared genes (being them also more similar) with the complete genomes of vertebrates than with insects and nematodes $[18,19]$. These results further support the idea that ancient genomes were gene rich, and that lineage specific gene gain and loss events were frequent during metazoan evolution, particularly within the ecdysozoans [32]. While the relevance of genes shared between trematodes and their hosts has been highlighted, since they may be crucial for parasite adapta- 


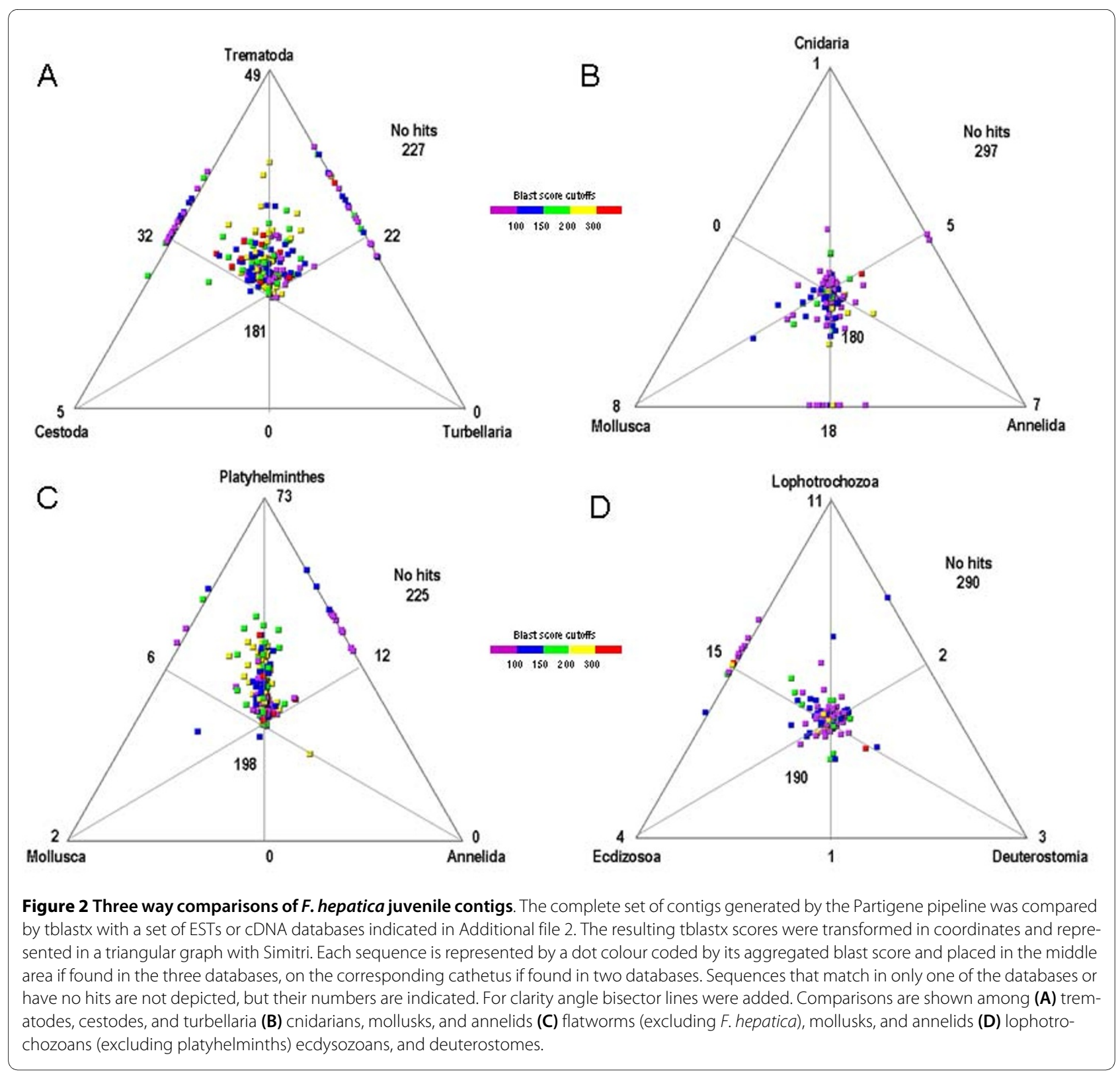

tion to the host [33], the inverse situation (genes present in the parasite but absent in their hosts), might provide relevant candidates for anti-parasitic intervention.

Additionally, since we included in the study partial genomes from other lophotrochozoans (annelids and mollusks) we were able to compare the Fasciola dataset to these organisms and other phyla. This is relevant since flatworm position in modern phylogeny is still debated, being placed either within or as sister group of the lophotrochozoa [34-36]. The conserved set of liver fluke genes is almost equally distant from cnidarians, mollusks, and annelids, but slightly closer to the two lophotrochozoans than the model ecdysozoans or vertebrates (Figure 2B, D, and Additional File 4). The trend in this (and all other comparisons performed) were maintained when including the 4089 F. hepatica adult contigs suggesting that the effects observed might not be due to sampling bias (data not shown). The comparisons here presented are consistent with the placement of flatworms basal to the lophotrochozoans.

\section{Compositional characteristics of F. hepatica predicted proteins}

The average $\mathrm{G}+\mathrm{C}$ content of the $F$. hepatica ESTs (both juvenile or adult) was $45 \%$, a value substantially higher than in S. mansoni and S. japonicum (34\%) [37]. Since variation in $\mathrm{GC}$ content can result in skewed codon usage [38], we analyzed the frequency of codons and amino 
acids of the predicted protein coding sequences in all $F$. hepatica available assemble ESTs (NEJ and adult stage), and compared it to those observed in other trematodes. As indicated in Figure 3A, there is a detectable difference in codon frequency, between the schistosomes and the other trematodes (including $F$. hepatica). Schistosomes prefer the most AU rich codon of each synonymous family, and are also strongly biased against $\mathrm{C}$ or $\mathrm{G}$ in the third codon position confirming early predictions obtained with limited gene sets [39]. More striking is the fact that significant differences were also found at the amino acid level, where schistosomes uses less Arg, Ala and Gly, and are enriched in Asn, Ile and Ser (Figure 3B). In a recent paper the tRNA complement of S. mansoni and S. japonicum is analyzed, but no significant correlation between tRNA copy number with the overall codon usage were found in any of the species [40]. The biological and evolutionary significance of the differences here observed is not clear, and deserves further consideration. In any case, these results raise the question that schistosomes might represent a more divergent than expected model for other trematodes.

\section{Gene Ontology classification and functional annotation}

Gene Ontology (GO) provides a useful way of classifying and annotating sequence information. Our analysis of the F. hepatica juvenile dataset showed up to $179 \mathrm{NEJ}$ contigs with GO assignment. The molecular function classification showed a predominance of the binding category overlapping with almost all other categorizations, followed by enzymes (catalytic activity) and structural components. The discrimination within the binding class showed three main divisions of similar relevance, two overlapping with enzymes and ribosomal proteins and a set identified as protein and DNA binding associated with regulatory functions (Figure 4A). The more represented biological process categories were linked with metabolism, regulation and development (Figure 4B), showing a consistent assignment of GO cellular components (data not shown). Functional annotation of predicted proteins showed a general representation of the diverse biological functions. Proteases and antioxidant enzymes should be highlighted since they have long been under scrutiny for their putative involvement in invasion and immune evasion processes [9,10,41-49]. Novel proteins included ribosomal proteins (Additional File 5) sev-

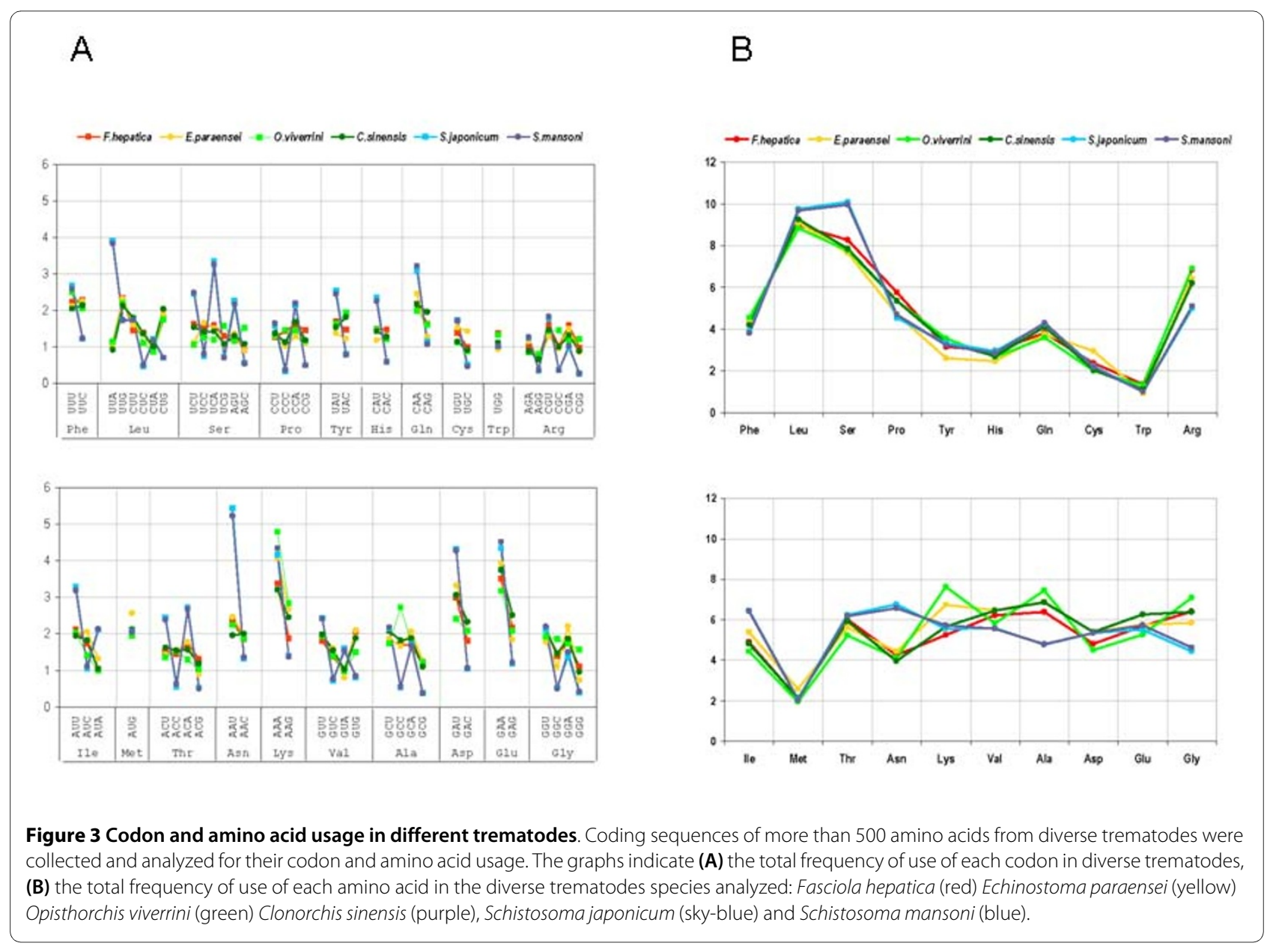




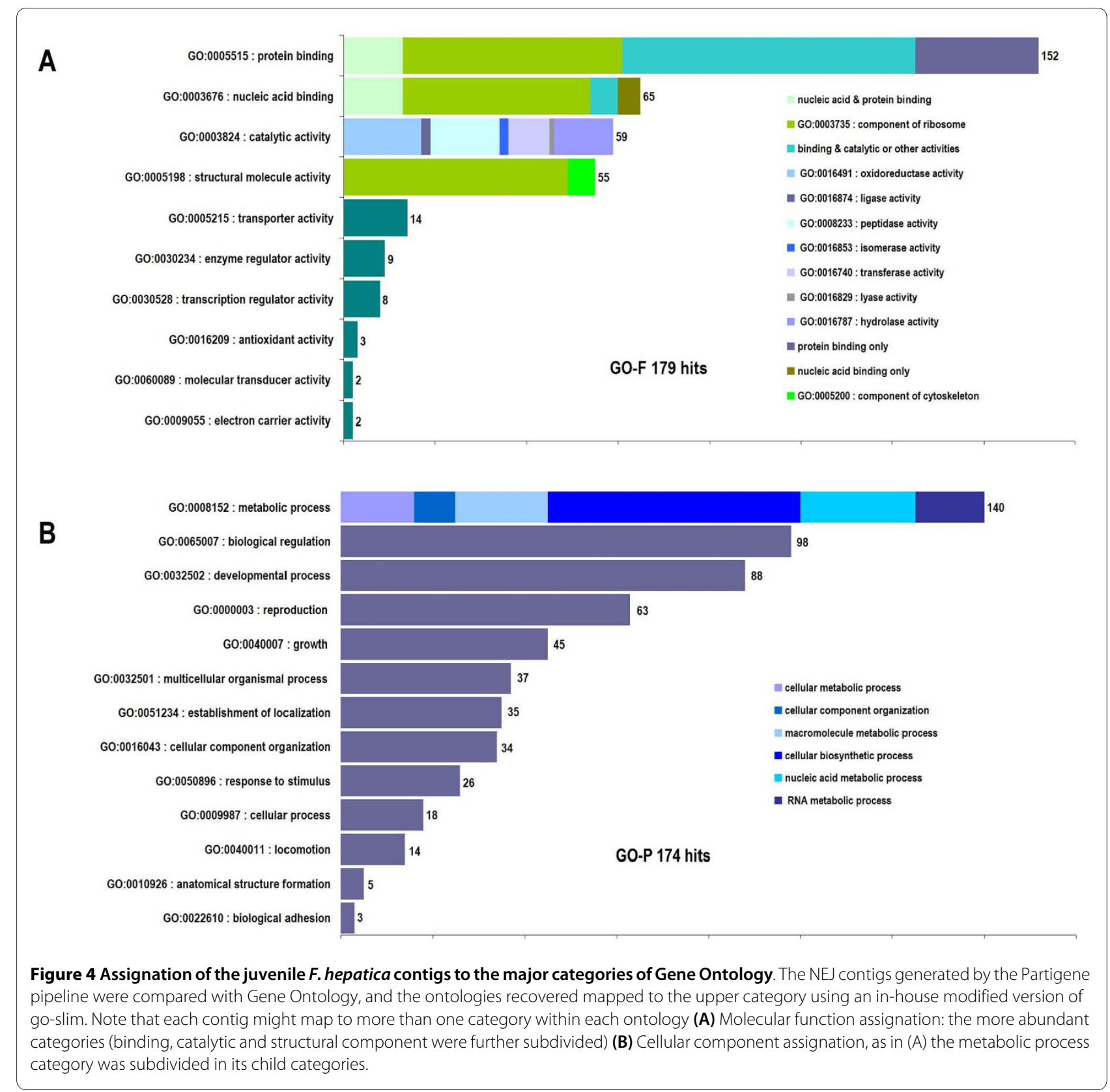

eral factors associated with protein and gene expression, cell signaling and apoptosis, as well as orthologues of candidate antigens that induce protection against other helminthiasis. They include tetraspanin-like protein [50], a membrane spanning protein located at the tegument of $S$. mansoni, Sm22.6 tegument antigen [51], and venom allergen-like (VAL) proteins, a candidate vaccine antigen against Necator americanus and Ancylostoma caninum [52-55].

\section{Relevant molecules for parasitism}

Despite the small size of our juvenile library the more represented sequences included proteinases and antioxi- dant enzymes previously reported as being predominantly expressed in NEJ [12,56-60], together with predicted proteins of unknown function conserved only in F. hepatica or in other trematodes but not in other taxa (Table 2).

Secreted cathepsins were among the more represented transcripts in juvenile ESTs, and also in the adult dataset (Table 2, Additional File 6). A more detailed analysis of these transcripts showed that different isoforms are are being expressed by the invading and adult stage. While cathepsins L3, L4 and L6 are detected in the juvenile ESTs, they are absent from the much larger adult dataset (with the exception of cathepsins L4). Proteomic analysis 
Table 2: Contigs including more reads in the F. hepatica NEJ ESTs assembly

\begin{tabular}{|c|c|c|c|c|c|c|c|c|c|c|c|c|c|}
\hline \multirow[t]{2}{*}{ Contig } & \multirow[t]{2}{*}{ Length } & \multirow[t]{2}{*}{ Reads } & \multirow[t]{2}{*}{ Signal_P* } & \multirow[t]{2}{*}{ TMHMM** } & \multirow[t]{2}{*}{ Description $^{* * *}$} & \multicolumn{8}{|c|}{ Distribution } \\
\hline & & & & & & FHE & TRE & CES & TUR & CND & LTZ & ECZ & DTS \\
\hline $\mathrm{FHC00023}$ & 824 & 57 & SPep & 0 & Similar to FHA01510_1 & $\mathbf{x}$ & & & & & & & \\
\hline $\mathrm{FHC00067}$ & 483 & 30 & SPep & 1 & No hit & & & & & & & & \\
\hline FHC00049 & 1130 & 27 & - & 0 & cathepsin B3 & $\mathbf{x}$ & $x$ & $x$ & $x$ & $x$ & $x$ & $x$ & $x$ \\
\hline $\mathrm{FHC00068}$ & 615 & 21 & - & 0 & Similar to AT006824 C. sinensis clone & $x$ & $x$ & & & & & & \\
\hline FHC00138 & 876 & 18 & - & 0 & Thioredoxin peroxidise & $x$ & $\mathbf{x}$ & $x$ & $x$ & $x$ & $x$ & $x$ & $x$ \\
\hline FHC00005 & 792 & 16 & SAnc & 3 & Similar to AT009818 C. sinensis clone & $x$ & $x$ & & & & & & \\
\hline $\mathrm{FHC00024}$ & 1064 & 14 & SPep & 0 & cathepsin L3 & $\mathbf{x}$ & $x$ & $x$ & $x$ & $x$ & $x$ & $x$ & $x$ \\
\hline $\mathrm{FHC00014}$ & 612 & 12 & SAnc & 2 & Similar to AT009818 C. sinensis clone & $\mathbf{x}$ & $x$ & & & & & & \\
\hline FHC00006 & 501 & 12 & SPep & 1 & Similar to AT009816 C. sinensis clone & $\mathbf{x}$ & $x$ & & & & & & \\
\hline FHC00095 & 699 & 11 & - & 0 & Similar to FhAE00302 & $\mathbf{x}$ & & & & & & & \\
\hline FHC00061 & 819 & 10 & SAnc & 3 & Similar to AT008757 C. sinensis clone & $\mathbf{x}$ & $x$ & & & & & & \\
\hline FHC00091 & 443 & 10 & - & 0 & cysteine-rich intestinal protein & $\mathbf{x}$ & $x$ & $x$ & $x$ & $x$ & $x$ & $x$ & $x$ \\
\hline $\mathrm{FHC00340}$ & 362 & 9 & - & 0 & Similar to FHA01532_1 & $x$ & & & & & & & \\
\hline $\mathrm{FHC00174}$ & 413 & 9 & - & 0 & Similar to OvAE2228 O. viverrini & & $x$ & $x$ & $x$ & $x$ & $x$ & & \\
\hline $\mathrm{FHC00054}$ & 610 & 8 & - & 0 & pro-cathepsin B1 & $x$ & $x$ & $x$ & $x$ & $x$ & $\mathrm{x}$ & $x$ & $x$ \\
\hline FHC00376 & 473 & 8 & SAnc & 1 & FN5 protein & $x$ & $\mathrm{x}$ & $x$ & $x$ & & $x$ & & $x$ \\
\hline FHC00101 & 564 & 7 & - & 0 & Peptidyl-prolyl cis-trans isomerase & $\mathbf{x}$ & $x$ & $x$ & $x$ & $x$ & $x$ & $x$ & $x$ \\
\hline $\mathrm{FHC00017}$ & 1131 & 7 & SPep & 0 & pro-cathepsin B2 & $\mathbf{x}$ & $\mathbf{x}$ & $x$ & $x$ & $\mathbf{x}$ & $\mathbf{x}$ & $x$ & $x$ \\
\hline FHC00175 & 930 & 7 & - & 0 & Ribosomal protein S2 & $\mathbf{x}$ & $\mathbf{x}$ & $x$ & $x$ & $x$ & $x$ & $\mathbf{x}$ & $x$ \\
\hline $\mathrm{FHC00013}$ & 252 & 7 & - & 0 & Ribosomal protein S29 & $x$ & $x$ & $x$ & $x$ & $x$ & $x$ & $x$ & $x$ \\
\hline FHC00187 & 282 & 7 & - & 0 & Calcium-binding protein & $x$ & $x$ & $x$ & $x$ & $x$ & $x$ & & \\
\hline FHC00030 & 680 & 6 & SPep & 0 & Cellular nucleic acid-binding protein & $x$ & $x$ & $x$ & $x$ & $x$ & $x$ & $x$ & $x$ \\
\hline FHC00018 & 289 & 6 & - & 0 & Similar to FhAE00481 & $x$ & $x$ & & & & & & \\
\hline $\mathrm{FHC00038}$ & 416 & 6 & SAnc & 1 & no hit & & & & & & & & \\
\hline FHC00172 & 476 & 6 & SPep & 0 & Similar to FhAE00307 & $x$ & & & & $x$ & & & \\
\hline
\end{tabular}

* Signal P results indicating prediction of a signal peptide or a signal anchor

** Number of predicted transmembrane domains as predicted by THMMM is indicated

*** Presence of a putatively relevant blast hit in different taxons is indicated. Hits below $\mathrm{e}^{-10}$ represented by a lowercase $\mathrm{X}$, under $\mathrm{e}^{-50}$ by uppercase $\mathrm{X}$, and $\mathrm{e}^{-100}$ in bold $\mathrm{X}$.

Columns headings are FHE (F. hepatica adult stage), TRE (other trematoda), CES (cestoda), TUR (turbellaria), CND (cnidaria), LTZ (lophotrochozoa), ECZ (ecdysozoa), DTS (deuterostomia) 
have shown that cathepsins L1 and L2 are clearly predominant in adults, in agreement with the relative abundance of their transcripts in the adult EST database [13] (Additional File 6), and it has been proposed that the repertoire of cathepsin Ls gradually change from those expressed in juveniles to a different set characteristic of the adults worms [13-15]. Interestingly, it has recently been reported that the juvenile predominant cathepsin L3 has a strong collagenase activity, that might result essential for the invasion process [61], while the "adult" cathepsin L1 is involved in hemoglobin degradation [14].

We found evidence that within the less characterized cathepsin B gene family a similar phenomenon might be taking place. The cathepsin B forms that appear as frequent in juveniles are quite distinct to the cathepsin B transcripts found in the adult stage dataset (Additional Files 7 and 8), suggesting that they might also be functionally distinct; cathepsin B1 functions as a digestive enzyme in the juvenile gut [62].

Further evidence that changing repertoires of enzymes within gene families might be a common theme in the parasite adaptation to the diverse environments found in their hosts is provided by the legumains. These enzymes have been proposed to have a relevant role activating other enzymes in helminth proteolytic cascades $[12,13,63-67]$. A novel legumain detected in the juvenile ESTs, legumain 3 has an inverted expression pattern with the previously reported legumain isolated from adult worms (Additional File 9, panels A, B). Besides the already described cathepsins and legumains, the degradome of the juvenile liver fluke was enriched by other proteases, including a novel serine proteinase, calciumdependent cysteine proteinases (calpains), and components of the proteasome and ubiquitin pathway (Table 3). Proteinase inhibitors like cystatins were also produced by the juvenile larvae. These might modulate parasite proteases on the host immune response as was described for nematode cystatins [68-71].

Sequences encoding detoxifying enzymes like thireodoxin peroxidase (TPx), superoxide dismutase (SOD), thioredoxin 2, glutation S-transferases and a novel glutathione peroxidase not previously reported in F. hepatica were also found in juveniles, stressing their relevance for immune evasion [72]. In flatworms thioredoxin and glutathione peroxidases are the main enzymes involved in detoxifying reactive oxygen species produced by host immune effector cells [73,74].

Secreted and surface proteins that may modulate host interactions are considered as relevant targets for vaccine or anti-parasitic drug design [75]. SignalP analysis identified putative signal peptides in $60 \mathrm{NEJ}$ predicted proteins, while 52 had an N-terminal signal anchor peptide. Several putative secreted proteins were novel (with no significant hits) or conserved only in trematodes but not detected in other taxa. Some of these transcripts were among the more represented ESTs in juveniles (Table 2). The repeated detection of these transcripts in partial datasets from diverse trematodes support the notion that they are truly highly expressed genes in trematodes, and may be important mediators for parasitism. We selected Contig FHC00023, a predicted secreted protein of unknown function that is the most frequent in the juvenile ESTs with no homologies outside $F$. hepatica for further analysis. By real time PCR we found that this transcript is predominantly expressed in the invasive stage confirming the in silico observation (Additional File 9 panel C). The putative ORF is characterized by repeated Ser and Thr residues predicted to be glycosilated, and in further analysis showed faint homology with mucins. Parasite-specific proteins (with no counterparts in vertebrates) like these are ideal targets for development of therapeutic agents since they would have no cross-reactivity with host molecules. The elucidation of the function of these proteins is an important task. The growing availability of functional genomics tools like RNA interference in $F$. hepatica and model trematodes [76-78] offers some hope this can be accomplished.

\section{Conclusions}

The data presented here provides an initial picture of the transcriptional status of the invasive stage of the zoonotic trematode $F$. hepatica, one of the most common parasites of livestock worldwide, and a relevant agent of human disease in impoverished areas of South America and Asia. Besides confirming previously identified genes involved in the invasion process, we also identified plausible candidates for anti-helminthic intervention. A set of putative $F$. hepatica specific transcripts, together with other flatworm specific sequences identified, and a group of transcripts absent in their mammalian hosts, provide an initial framework to pinpoint novel targets for future anti-parasitic drugs or vaccine development. The availability of recently developed functional genomic tools in liver fluke offers a platform to start unraveling the function of these novel conserved genes. Furthermore, we detected interesting differences between the models Schistosoma species with other lineages of trematodes, suggesting that genomic and transcriptomic efforts in other flukes might be justified. Comparative studies between diverse trematodes would provide more clues on evolutionary adaptations to parasitism. The richness of information obtained from a limited set of data warrants an in dept analysis of the transcriptome using new multiparallel sequencing technologies.

\section{Methods \\ Parasites}

Fasciola hepatica metacercariae were obtained in our laboratory from experimentally infected Lymnaea viatrix snails and maintained encysted on $0.4 \%$ carboxymethyl 
Table 3: Putative host interacting proteins of NEJ of Fasciola hepatica

\begin{tabular}{|c|c|c|c|c|c|}
\hline Contig & e value & Best Hit Accesion & Species & Description & Pfam ID \\
\hline \multicolumn{6}{|l|}{ Proteases } \\
\hline FHC00852 & $4,00 E-68$ & Smp173840|29601 & S. mansoni & $\begin{array}{l}26 S \text { protease } \\
\text { regulatory subunit }\end{array}$ & PF00004.21 \\
\hline $\mathrm{FHC00017}$ & $1,00 \mathrm{E}-172$ & CAD32937 & F. hepatica & Pro-cathepsin B2 & PF00112.15 \\
\hline FHC00024 & 0 & ACM67632 & F. hepatica & Cathepsin $2 \mathrm{~L}$ & PF00112.15 \\
\hline FHC00049 & 0 & ABU62925 & F. hepatica & Cathepsin B3 & PF00112.15 \\
\hline FHC00054 & $1,00 \mathrm{E}-103$ & CAD32937 & F. hepatica & Pro-cathepsin B2 & PF00112.15 \\
\hline FHC00092 & $2,00 \mathrm{E}-57$ & ABU62925 & F. hepatica & Cathepsin B & PF00112.15 \\
\hline FHC00154 & $3,00 \mathrm{E}-40$ & ABZ80402 & F. hepatica & Cathepsin L6 & PF00112.15 \\
\hline FHC00522 & $1,00 \mathrm{E}-34$ & ABW75768 & F. hepatica & Procathepsin L & PF00112.15 \\
\hline FHC00855 & $2,00 E-69$ & ABU62925 & F. hepatica & Cathepsin B & PF00112.15 \\
\hline FHC00201 & $1,00 \mathrm{E}-112$ & CAC85636 & F. hepatica & $\begin{array}{l}\text { Legumain like } \\
\text { precursor }\end{array}$ & PF01650.10 \\
\hline FHC00383 & $2,00 \mathrm{E}-44$ & CAC85636 & F. hepatica & $\begin{array}{l}\text { Legumain like } \\
\text { precursor }\end{array}$ & PF01650.10 \\
\hline FHC00251 & $1,00 \mathrm{E}-27$ & CAC85636 & F. hepatica & $\begin{array}{l}\text { Legumain like } \\
\text { precursor }\end{array}$ & - \\
\hline $\mathrm{FHC00413}$ & $2,00 \mathrm{E}-32$ & CAC85636 & F. hepatica & $\begin{array}{l}\text { Legumain like } \\
\text { precursor }\end{array}$ & - \\
\hline FHC00456 & $5,00 \mathrm{E}-22$ & Smp002150|29044 & S. mansoni & Serine protease & PF00089.18 \\
\hline FHC00410 & $7,00 \mathrm{E}-09$ & CPRT0000007748 & S. japonicum & $\begin{array}{l}\text { Probable Ufm1- } \\
\text { specific protease } 2\end{array}$ & - \\
\hline $\mathrm{FHC00435}$ & $8,00 \mathrm{E}-46$ & B7P5Y9_IXOSC & I. scapularis & $\begin{array}{l}\text { Calcium-dependent } \\
\text { cysteine protease }\end{array}$ & - \\
\hline \multicolumn{6}{|c|}{ Proteinase Inhibitors } \\
\hline FHC00812 & $2,00 \mathrm{E}-16$ & Q06K58_PHLDU & P. duboscai & $\begin{array}{l}\text { Endopeptidase } \\
\text { inhibitor }\end{array}$ & PF10208.1 \\
\hline FHC00195 & $1,00 \mathrm{E}-57$ & AAV68752 & F. hepatica & cystatin & - \\
\hline $\mathrm{FHC00724}$ & $7,00 \mathrm{E}-13$ & AAV68752 & F. hepatica & cystatin & - \\
\hline \multicolumn{6}{|c|}{ Antioxidant proteins } \\
\hline FHC00138 & $1,00 \mathrm{E}-131$ & ACI04165 & F. hepatica & $\begin{array}{l}\text { Thioredoxin } \\
\text { peroxidase }\end{array}$ & PF00578.13 \\
\hline FHC00167 & $5,00 \mathrm{E}-37$ & DQ821492 & Haliotis discus & $\begin{array}{l}\text { Cu/Zn-superoxide } \\
\text { dismutase }\end{array}$ & PF00080.12 \\
\hline FHC00152 & $9,00 \mathrm{E}-10$ & CPRT0000000157 & S. japonicum & $\begin{array}{l}\text { Thioredoxin-like } \\
\text { protein }\end{array}$ & PF06110.3 \\
\hline FHC00111 & $3,00 \mathrm{E}-39$ & Al446859 & E. paraensei & $\begin{array}{l}\text { Glutathione S- } \\
\text { Transferase }\end{array}$ & PF02798.12 \\
\hline $\mathrm{FHC} 00287$ & $5,00 \mathrm{E}-90$ & Al446859 & E. paraensei & $\begin{array}{l}\mu \text {-Glutathione } S \text { - } \\
\text { Transferase }\end{array}$ & PF02798.12 \\
\hline FHC00081 & $2,00 \mathrm{E}-57$ & АТ007109 & P. westermani & $\begin{array}{l}\text { Glutathione } \\
\text { peroxidase }\end{array}$ & PF00255.11 \\
\hline FHC00066 & $7,00 \mathrm{E}-49$ & AT006971 & C. sinensis & $\begin{array}{l}\text { Thioredoxin-2 } \\
\text { mitochondrial }\end{array}$ & PF00085.12 \\
\hline
\end{tabular}


Table 3: Putative host interacting proteins of NEJ of Fasciola hepatica (Continued)

\begin{tabular}{|c|c|c|c|c|c|}
\hline \multicolumn{6}{|c|}{ Transmembrane proteins } \\
\hline FHC00555 & $5,00 \mathrm{E}-26$ & CPRT0000008170 & S. japonicum & $\begin{array}{l}\text { Clathrin coat- } \\
\text { associated protein }\end{array}$ & PF01217.12 \\
\hline FHC00086 & $6,00 \mathrm{E}-32$ & O01372_SCHJA & S. japonicum & $\begin{array}{l}22.6 \mathrm{kDa} \text { membrane- } \\
\text { associated antigen }\end{array}$ & PF00036.24 \\
\hline FHC00009 & $9,00 \mathrm{E}-54$ & CPRT0000003434 & S. japonicum & $\begin{array}{l}\text { Transmembrane } \\
\text { emp24 protein }\end{array}$ & PF01105.16 \\
\hline FHC00592 & $2,00 \mathrm{E}-13$ & Fgf & H. sapiens & $\begin{array}{l}\text { FGF receptor } \\
\text { activating proteín }\end{array}$ & PF10277.1 \\
\hline FHC00037 & $7,00 \mathrm{E}-34$ & AAA31753 & F. hepatica & $\begin{array}{l}\text { NADH } \\
\text { dehydrogenase } \\
\text { subunit } 3\end{array}$ & PF00507.11 \\
\hline FHC00241 & $9,00 \mathrm{E}-53$ & CPRT0000009505 & S. japonicum & $\begin{array}{l}\text { Succinate } \\
\text { dehydrogenase } \\
\text { complex, subunit C }\end{array}$ & PF01127.14 \\
\hline FHC00273 & $3,00 E-24$ & Smp140000|29115 & S. mansoni & $\begin{array}{l}\text { Tetraspanin-CD63 } \\
\text { receptor }\end{array}$ & PF00335.12 \\
\hline FHC00300 & $1,00 \mathrm{E}-11$ & CPRT0000000388 & S. japonicum & $\begin{array}{l}\text { Ssr4; signal sequence } \\
\text { receptor }\end{array}$ & - \\
\hline FHC00606 & $1,00 \mathrm{E}-06$ & Smp156020|29231 & S. mansoni & Glucose transporter & - \\
\hline \multicolumn{6}{|c|}{ Cell signalling } \\
\hline $\mathrm{FHC00043}$ & $3,00 E-31$ & A4V9Q6_FASHE & F. hepatica & $\begin{array}{l}\text { Calmodulin-like } \\
\text { protein } 2\end{array}$ & PF00036.24 \\
\hline FHC00494 & $1,00 \mathrm{E}-100$ & CPRT0000000218 & S. japonicum & $\begin{array}{l}\text { Phosphatase 2A } \\
\text { inhibitor }\end{array}$ & PF00956.10 \\
\hline FHC00519 & $2,00 \mathrm{E}-10$ & CED3_CAEEL & C. elegans & Caspase-2 & PF00656.14 \\
\hline FHC00285 & $2,00 \mathrm{E}-43$ & CPRT0000001178 & S. japonicum & $\begin{array}{l}\text { Cell cycle and } \\
\text { apoptosis regulatory } \\
\text { protein } 1\end{array}$ & PF02037.19 \\
\hline FHC00631 & $1,00 \mathrm{E}-65$ & A4IF06_CLOSI & C. sinensis & Bax inhibitor factor 1 & PF01027.12 \\
\hline FHC00565 & $3,00 E-44$ & Smp_073560 & S. mansoni & $\begin{array}{l}\text { WD domain G beta- } \\
\text { like protein }\end{array}$ & PF00400.24 \\
\hline $\mathrm{FHC00052}$ & $7,00 \mathrm{E}-29$ & MADD_DROME & D. melanogaster & $\begin{array}{l}\text { MAP kinase- } \\
\text { activating death } \\
\text { domain protein }\end{array}$ & - \\
\hline \multicolumn{6}{|c|}{ Structural and motor proteins } \\
\hline FHC00033 & $4,00 \mathrm{E}-74$ & EL620294 & O. viverrini & Actin 2 & PF00022.11 \\
\hline FHC00117 & $1,00 \mathrm{E}-149$ & EL620294 & O. viverrini & Actin 2 & PF00022.11 \\
\hline FHC00487 & $1,00 \mathrm{E}-26$ & C610909 & L. rubellus & $\begin{array}{l}\text { Actin related protein } \\
2 / 3\end{array}$ & PF04699.6 \\
\hline FHC00379 & $2,00 \mathrm{E}-34$ & EL620325 & O. viverrini & Cofilin & PF00241.12 \\
\hline FHC00056 & $7,00 \mathrm{E}-53$ & EL620358 & O. viverrini & Dynein light chain & PF01221.10 \\
\hline FHC00197 & $1,00 \mathrm{E}-25$ & EL619926 & O. viverrini & Dynein Light Chain & PF01221.10 \\
\hline $\mathrm{FHC00363}$ & $3,00 \mathrm{E}-11$ & EL618949 & O. viverrini & Dynein LC6 & - \\
\hline FHC00802 & $4,00 E-37$ & CPRT0000002575 & S. japonicum & Paramyosin & PF01576.11 \\
\hline $\mathrm{FHC00440}$ & $1,00 \mathrm{E}-99$ & CAP72051 & F. hepatica & Tubulin beta-3 & PF03953.9 \\
\hline FHC00278 & $7,00 \mathrm{E}-21$ & CAP72050 & F. hepatica & Tubulin beta- 2 & - \\
\hline
\end{tabular}


cellulose until use. Excystment of metacercariae was performed as described previously [15]. Briefly, metacercariae were placed in a $100-\mu \mathrm{m}$ filter and incubated $5 \mathrm{~min}$ with $1 \%$ sodium hypochlorite, washed exhaustively with PBS and incubated at $39^{\circ} \mathrm{C}$ for up to 3 hours in a solution prepared by mixing equal volumes of $\mathrm{A}(0.4 \%$ sodium taurocholate, $120 \mathrm{mM} \mathrm{NaHCO}, 140 \mathrm{mM} \mathrm{NaCl}, \mathrm{pH} 8.0$ and $\mathrm{B}(50 \mathrm{mM} \mathrm{HCl}, 33 \mathrm{mM} \mathrm{L}$-cysteine). The emerging NEJs were collected in a $20 \mu \mathrm{m}$-filter with RPMI-1640 medium and used for RNA extraction.

\section{RNA extraction, ligation of RNA adaptors and CDNA synthesis}

Total RNA from 1200 NEJs was prepared using the Micro to Midi RNA Extraction Kit (Invitrogen), according to the manufacturer's protocol. Two hundred nanograms of total RNA were used for CDNA synthesis using the protocol described [28]. Briefly, the non capped RNAs were dephosphorylated, and the complete mRNAs were decapped by a pyrophosphatase treatment, and later ligated to the GeneRacer RNA oligo to introduce a 5' priming site in complete mRNAs. After this treatment, first strand synthesis was performed with the reverse transcriptase Superscript III (Invitrogen) using GeneRacer oligo-dT primer (5'GCTGTCAACGATACGCTAC GTAACGGCATGACAGTG(T) $)_{18} 3^{\prime}$ ).

\section{Preparation of NEJ CDNA libraries}

Amplification of full-length cDNAs was performed by PCR using universal forward (GeneRacer 5'Nested: 5'GGACACTGACATGGACTGAAGGAGTA3') and reverse primers (GenerRacer 3'Nested: 5'CGCTACGTAACGGCATGACAGTG3') provided by the GeneRacer kit. PCR was carried out for 30 cycles $\left(94^{\circ} \mathrm{C}, 45 \mathrm{sec} ; 68^{\circ} \mathrm{C} 45 \mathrm{sec} ; 72^{\circ} \mathrm{C} 5 \mathrm{~min}\right)$ using Hot Start Taq DNA polymerase (Fermentas). PCR products were size fractionated in three subpopulations $(300-800 \mathrm{bp}$, 800-2000 bp and $>2000$ bp) by excision from $1 \%$ TBE agarose gels, purified with QIAquick Gel Extraction kit (QIAGEN), ligated to pCR4-TA cloning vectors (Invitrogen), electroporated into One Shot TOP 10 Electrocompetent $E$. coli (Invitrogen), and plated on LB Amp/X-Gal. Recombinant clones from the libraries were randomly picked, grown in Circle Growth medium and stocked at $80^{\circ} \mathrm{C}$ in 96 -well plates in $30 \%$ glycerol.

\section{DNA sequencing and Bioinformatics analysis}

Clones were cultured in 96 well plates with Circle Growth media and plasmid DNA was purified by alkaline lysis in 96 well plates. DNA was sequenced with M13 reverse primers using the Dyenamic ET Dye Terminator cycle sequencing kit for MegaBace DNA Analysis Systems (GE Healthcare Life Sciences) according to the manufacturer's instructions.
The sequence reads obtained were processed and analyzed using the Partigene pipeline [29]. Briefly, Trace2dbest [79] processed the chromatograms removing low quality (Phred $<15,<150 \mathrm{bp}$ ) and vector sequences, and the resulting preprocessed ESTs were assembled in a two-step process carried out by CLOBB [80] and Phrap programs; the resulting contigs and singletons were compared to a set of databases maintained locally (listed in Supplementary Table 1) using tBLASTX and BLASTX. Functional categories were analyzed using annot8r [81]. Signal sequence prediction was performed using SignalP3.0 program [82]. Prediction of trans-membrane domains were conducted using TMHMM software [83]. Blast results comparisons were performed with Simitri [31]. All the available ESTs reads from adult stage of $F$. hepatica available at the Wellcome Trust Sanger Institute http://www.sanger.ac.uk/Projects/Helminths were downloaded and processed with the same pipeline. The juvenile sequences here obtained were deposited at the dbEST with the accessions GT740211 to GT741887.

\section{Codon usage and amino acid frequencies}

For F. hepatica adult and juvenile stages, Echinostoma paraensei, Opistorchis viverrini and Clonorchis sinensis, open reading frames were predicted from the assembled EST data using EMBOSS bioinformatics suite [84]. The longest ORF from each EST was retrieved and the predicted protein sequence was blasted against the NCBI nr databank. ORFs with significant hits were kept for further analysis. For S. japonicum and S. mansoni predicted coding regions obtained through the respective genome projects were analyzed. Codon and amino acid usage was calculated using GCUA: General Codon Usage Analysis tool [85]

\section{Real time PCR}

Real time PCR experiments were carried out in an Applied Biosystems 7500 Real time PCR System. Ten microliters of different dilutions of cDNA of NEJ and adult parasites were amplified using $0.2 \mu \mathrm{M}$ each specific primers, $1.5 \mathrm{mM} \mathrm{MgCl}_{2}, 25 \mathrm{uM}$ dNTPs, $0.25 \mathrm{U}$ Platinun Taq DNA polymerase (Invitrogen), $1 \times$ SYBR Green, $1 \times$ PCR buffer in a $20 \mathrm{uL}$ volume reaction. Primers sequences are $\beta$-actin (Forward 5'-GTGTTGGATTCTGGTGATGGTGTC-3' and Reverse 5'-CAATTTCTCCTTGAT GTCTCG-3'), FHC00023 (Forward 5'-ATGG TGCGAACGCTAAG-3' and Reverse 5'-GAAGAACGCAACGCCGAAGA-3'), Legumain 1 (Forward 5'CAAGGATGTTTATGAAGGG-3'and Reverse 5'-TGC TTTGTTCATGCTGGC-3') Legumain 3 (Forward 5'-AG CAGACAAAACCCTTATCGT-3'and Reverse 5'-GGA ATAATAGTAGGCGACGTG-3'). Reactions were performed in triplicate using the following PCR amplification conditions, 1 cycle $\left(94^{\circ} \mathrm{C}, 5 \mathrm{~min}\right), 40$ cycles $\left(94^{\circ} \mathrm{C}, 15\right.$ 
seg; $60^{\circ} \mathrm{C}, 10 \mathrm{seg} ; 72^{\circ} \mathrm{C}, 15 \mathrm{seg}$ ). All results were analyzed using the $2^{-\Delta \Delta \mathrm{Ct}}$ method and $\beta$-actin as internal control group [86].

\section{Note added in proof}

Recently a separate study describing the generation of more than 500,000 sequences from an adult cDNA library using 454 sequencing was published [87]. However, at the time of writing these sequences have not been made publically accessible and hence a comparative analysis of this dataset was not possible.

\section{Additional material}

\begin{abstract}
Additional file 1 Figure S1. cDNA library generation procedure. (A) Diagrammatic representation of the major steps in the CDNA library construction. (B) Details on the full length selection and adapter ligation. (C) Representative PCR products from colonies obtained after size fractionation; left: small size insert library, right: large size insert library.
\end{abstract}

Additional file $\mathbf{2}$ Table S1- Databases used in this study. Details and links to the databases used in this study.

Additional file 3 Table S2- Overview of $F$. hepatica adult ESTs assembly. Details of the assembly of the available adult stage ESTs with the Partigene pipeline.

Additional file 4 Figure S2. Three way comparisons of $F$. hepatica juvenile contigs against early metazoans and model organisms. (A) The complete set of contigs generated by the Partigene compared to ESTs from the early metazoans (non bilaterians) Trichoplax adherens, Porifera (sponges) and Cnidaria (jellyfish and corals). (B) Comparison among the nematode C. elegans, the insect D. melanogaster and the arachnid (thick) I. scapularis. (C) Comparison to the vertebrates D. renio (zebra fish), G. gallus (chicken) and H. sapiens (human).

Additional file $\mathbf{5}$ Table S3- Ribosomal proteins detected in NEJ EST assembly. List of ribosomal proteins detected in the juvenile assembly. Additional file 6 Table S4- Most abundant contigs in the F. hepatica adult EST assembly Details of the contigs containing more reads in the adult stage assembly.

Additional file 7 Figure S3. Phylogenetic tree of Fasciolidae cathepsins B. Bootstrapped neighbor joining tree of available cathepsin B coding sequences, showing the clustering of juvenile and adult forms. Sequences are color coded by their stage origin: adult stage represented in red rhombs, juveniles in blue triangles and metacercariae in green circles. Contig sequences from ESTs projects (Sanger Center and this study) are unfilled. Sequences from F. gigantica are underlined. Sequences from GeneBank are named following the same criterion of Robinson et al [14], namely the first two characters indicate species (Fh or Fg for F. hepatica or F. gigantica respectively) followed by the cathepsin type, country of origin, accession, stage and $\mathrm{P}$ or $\mathrm{C}$ for describing partial or complete coding sequences respectively. The "adult" and "juvenile" clusters observed are not due to sample bias since they are maintained when analyzing partial regions corresponding to 5 ' or 3 'ends of the ESTs (data not shown). The nucleotide sequence alignment of the cathepsins B used to generate the tree is available as Additional File 8.

Additional file 8 Supplementary Data S1 - Alignment of cathepsin B sequences. Nucleotide sequence alignment of cathepsin B sequences. Additional file 9 Figure S4. Differentially expressed genes in F. hepatica. Transcriptional levels of legumain 1 (A) legumain 3 (B) and Contig FHC00023 (C) were determined by Real time RT-PCR in newly excysted juveniles and adults. Levels were measured by the 2-delta delta CT method using actin as a control for normalization.

Authors' contributions

$M C, C C, A Z$, \& JFT conceived the work. MC, GR, LR \& NDO obtained the RNA and generated the libraries. MC, ES, NR \& NDO amplified the library and sequenced the clones. NR, PS \& FAV organized the analysis pipeline, and MC,
NR, NDO \& PS processed the sequence data, MC, CC, AZ and JFT wrote the manuscript, which was discussed, improved and corrected by all participant authors. All authors read and approved the final manuscript.

\section{Acknowledgements}

We would like to thank Dr. Henrique Ferreira (UFRGS, Brazil), Dr. Cecilia Fernandez (Fac. Química, UDELAR, Uruguay) and MSc. Daniel Acosta (Fac. Ciencias, UDELAR, Uruguay) for technical expertise and helpful discussions during the course of this work. We thank the Biotechnology Center at UFRGS, Brazil for kindly providing the sequencing facilities for EST generation, and Dr. Edmundo Grisard at the Bioinformatics Laboratory (UFSC, Brazil) for allowing us to use the GARSA pipeline at the initial stage of sequence analysis, Dr. Paul Brindley (George Washington Univ, USA) for critically reading the manuscript, and Dr. Matt Berriman (Wellcome Trust Sanger Institute) for gently allowing us to use the adult F. hepatica ESTs data. These data were generated at the Wellcome Trust Sanger Institute and are available for download from http:// www.sanger.ac.uk/Projects/Helminths.

This work was supported by Fundación Manuel Perez, Uruguay, Proy. Binacional DICYT-CNPq, CSIC-Udelar, Pedeciba and INIA-FTPA-252. M.C. and E.S. are recipients of Conselho Nacional de Desenvolvimento Científico e Tecnológico (CNPq) fellowships.

\section{Author Details}

1Departamento de Biologia Molecular e Biotecnologia, Instituto de Biociências e Programa de Pós-Graduação em Biologia Celular e Molecular, Centro de Biotecnologia, Universidade Federal do Rio Grande do Sul, UFRGS, Porto Alegre, Brazil, ${ }^{2}$ Departamento de Genética, Facultad de Medicina, Universidad de la República, UDELAR, Montevideo, Uruguay, ${ }^{3}$ Laboratorio de Biomatemáticas, Instituto de Biología, Facultad de Ciencias, Universidad de la República, UDELAR, Montevideo, Uruguay and ${ }^{4}$ Unidad de Biología Parasitaria, Instituto de Biología, Facultad de Ciencias, Universidad de la República, UDELAR, Montevideo, Uruguay

Received: 29 July 2009 Accepted: 7 April 2010

Published: 7 April 2010

\section{References}

1. Spithill TM, Smooker PM, Copeman DB: Fasciola gigantica: epidemiology, control, immunology and molecular biology. Edited by: Dalton JP. Fasciolosis CABI Publishing, Oxin, UK; 1999:465-525.

2. Mas-Coma S, Barques MD, Valero MA: Fascioliasis and other plant-borne trematode zoonoses. Int J Parasitol 2005, 35(11-12):1255-1278.

3. Garcia HH, Moro PL, Schantz PM: Zoonotic helminth infections of humans: echinococcosis, cysticercosis and fascioliasis. Curr Opin Infect Dis 2007, 20(5):489-494

4. Fairweather I: Triclabendazole: new skills to unravel an old(ish) enigma. J Helminthol 2005, 79(3):227-234

5. Fried B: Metacercarial excystment of trematodes. Adv Parasitol 1994 33:91-144.

6. Andrews SJ: The life cycle of Fasciola hepatica. Edited by: Dalton JP. Fasciolosis CABI Publishing, Oxin, UK; 1999:1-29.

7. Haroun ET, Hillyer GV: Resistance to fascioliasis--a review. Vet Parasitol 1986, 20(1-3):63-93

8. Piacenza L, Acosta D, Basmadjian I, Dalton JP, Carmona C: Vaccination with cathepsin $L$ proteinases and with leucine aminopeptidase induces high levels of protection against fascioliasis in sheep. Infect Immun 1999, 67(4):1954-1961.

9. Carmona C, Dowd AJ, Smith AM, Dalton JP: Cathepsin L proteinase secreted by Fasciola hepatica in vitro prevents antibody-mediated eosinophil attachment to newly excysted juveniles. Mol Biochem Parasitol 1993, 62(1):9-17.

10. Piedrafita D, Parsons JC, Sandeman RM, Wood PR, Estuningsih SE, Partoutomo S, Spithill TW: Antibody-dependent cell-mediated cytotoxicity to newly excysted juvenile Fasciola hepatica in vitro is mediated by reactive nitrogen intermediates. Parasite Immunol 2001, 23(9):473-482.

11. Piedrafita D, Spithill TW, Dalton JP, Brindley PJ, Sandeman MR, Wood PR, Parsons JC: Juvenile Fasciola hepatica are resistant to killing in vitro by free radicals compared with larvae of Schistosoma mansoni. Parasite Immunol 2000, 22(6):287-295. 
12. Tkalcevic J, Ashman K, Meeusen E: Fasciola hepatica: rapid identification of newly excysted juvenile proteins. Biochem Biophys Res Commun 1995, 213(1):169-174

13. Robinson MW, Menon R, Donnelly SM, Dalton JP, Ranganathan S: An integrated transcriptomic and proteomic analysis of the secretome of the helminth pathogen, Fasciola hepatica: proteins associated with invasion and infection of the mammalian host. Mol Cell Proteomics 2009.

14. Robinson MW, Tort JF, Lowther J, Donnelly SM, Wong E, Xu W, Stack CM, Padula M, Herbert B, Dalton JP: Proteomics and phylogenetic analysis of the cathepsin L protease family of the helminth pathogen Fasciola hepatica: expansion of a repertoire of virulence-associated factors. Mol Cell Proteomics 2008, 7(6):1111-1123.

15. Cancela M, Acosta D, Rinaldi G, Silva E, Duran R, Roche L, Zaha A, Carmona C, Tort JF: A distinctive repertoire of cathepsins is expressed by juvenile invasive Fasciola hepatica. Biochimie 2008, 90(10):1461-1475.

16. Verjovski-Almeida S, DeMarco R, Martins EA, Guimaraes PE, Ojopi EP, Paquola AC, Piazza JP, Nishiyama MY Jr, Kitajima JP, Adamson RE, Ashton PD, Bonaldo MF, Coulson PS, Dillon GP, Farias LP, Gregorio SP, Ho PL, Leite RA, Malaquias LC, Marques RC, Miyasato PA, Nascimento AL, Ohlweiler FP, Reis EM, Ribeiro MA, Sa RG, Stukart GC, Soares MB, Gargioni C, Kawano T, Rodrigues V, Madeira AM, Wilson RA, Menck CF, Setubal JC, Leite LC, DiasNeto E: Transcriptome analysis of the acoelomate human parasite Schistosoma mansoni. Nat Genet 2003, 35(2):148-157.

17. Hu W, Yan Q, Shen DK, Liu F, Zhu ZD, Song HD, Xu XR, Wang ZJ, Rong YP, Zeng LC, Wu J, Zhang X, Wang JJ, Xu XN, Wang SY, Fu G, Zhang XL, Wang ZQ, Brindley PJ, McManus DP, Xue CL, Feng Z, Chen Z, Han ZG: Evolutionary and biomedical implications of a Schistosoma japonicum complementary DNA resource. Nat Genet 2003, 35(2):139-147.

18. Berriman M, Haas BJ, LoVerde PT, Wilson RA, Dillon GP, Cerqueira GC, Mashiyama ST, Al-Lazikani B, Andrade LF, Ashton PD, Aslett MA, Bartholomeu DC, Blandin G, Caffrey CR, Coghlan A, Coulson R, Day TA, Delcher A, DeMarco R, Djikeng A, Eyre T, Gamble JA, Ghedin E, Gu Y, HertzFowler C, Hirai H, Hirai Y, Houston R, Ivens A, Johnston DA, Lacerda D, Macedo CD, McVeigh P, Ning Z, Oliveira G, Overington JP, Parkhill J, Pertea M, Pierce RJ, Protasio AV, Quail MA, Rajandream MA, Rogers J, Sajid M, Salzberg SL, Stanke M, Tivey AR, White O, Williams DL, Wortman J, Wu W, Zamanian M, Zerlotini A, Fraser-Liggett CM, Barrell BG, El-Sayed NM: The genome of the blood fluke Schistosoma mansoni. Nature 2009, 460(7253):352-358.

19. Liu F, Zhou Y, Wang ZQ, Lu G, Zheng H, Brindley PJ, McManus DP, Blair D, Zhang QH, Zhong Y, Wang S, Han ZG, Chen Z: The Schistosoma japonicum genome reveals features of host-parasite interplay. Nature 2009, 460(7253):345-351.

20. Brindley PJ, Mitreva M, Ghedin E, Lustigman S: Helminth genomics: The implications for human health. PLoS Negl Trop Dis 2009, 3(10):e538

21. Knox DP: Technological advances and genomics in metazoan parasites. Int J Parasitol 2004, 34(2):139-152.

22. Adema CM, Leonard PM, DeJong RJ, Day HL, Edwards DJ, Burgett G, Hertel LA, Loker ES: Analysis of messages expressed by Echinostoma paraensei miracidia and sporocysts, obtained by random EST sequencing. J Parasito/ 2000, 86(1):60-65.

23. Cho PY, Kim TI, Whang SM, Hong SJ: Gene expression profile of Clonorchis sinensismetacercariae. Parasitol Res 2008, 102(2):277-282.

24. Cho PY, Lee MJ, Kim TI, Kang SY, Hong SJ: Expressed sequence tag analysis of adult Clonorchis sinensis, the Chinese liver fluke. Parasitol Res 2006, 99(5):602-608

25. Lee JS, Lee J, Park SJ, Yong TS: Analysis of the genes expressed in Clonorchis sinensis adults using the expressed sequence tag approach. Parasitol Res 2003, 91(4):283-289.

26. Kim TS, de Guzman JV, Kong HH, Chung Dl: Comparison of gene representation between diploid and triploid Paragonimus westermani by expressed sequence tag analyses. J Parasitol 2006, 92(4):803-816.

27. Laha T, Pinlaor P, Mulvenna J, Sripa B, Sripa M, Smout MJ, Gasser RB, Brindley PJ, Loukas A: Gene discovery for the carcinogenic human liver fluke, Opisthorchis viverrini. BMC Genomics 2007, 8:189.

28. Fernandez C, Gregory WF, Loke P, Maizels RM: Full-length-enriched cDNA libraries from Echinococcus granulosus contain separate populations of oligo-capped and trans-spliced transcripts and a high level of predicted signal peptide sequences. Mol Biochem Parasitol 2002, 122(2):171-180.
29. Parkinson J, Anthony A, Wasmuth J, Schmid R, Hedley A, Blaxter M: PartiGene--constructing partial genomes. Bioinformatics 2004, 20(9):1398-1404.

30. Zurita M, Bieber D, Ringold G, Mansour TE: cDNA cloning and gene characterization of the mitochondrial large subunit (LSU) rRNA from the liver fluke Fasciola hepatica. Evidence of heterogeneity in the fluke mitochondrial genome. Nucleic Acids Res 1988, 16(14B):7001-7012.

31. Parkinson J, Blaxter M: SimiTri--visualizing similarity relationships for groups of sequences. Bioinformatics 2003, 19(3):390-395.

32. Putnam NH, Srivastava M, Hellsten U, Dirks B, Chapman J, Salamov A, Terry A, Shapiro H, Lindquist E, Kapitonov VV, Jurka J, Genikhovich G, Grigoriev IV, Lucas SM, Steele RE, Finnerty JR, Technau U, Martindale MQ, Rokhsar DS: Sea anemone genome reveals ancestral eumetazoan gene repertoire and genomic organization. Science 2007, 317(5834):86-94.

33. Venancio TM, DeMarco R, Almeida GT, Oliveira KC, Setubal JC, VerjovskiAlmeida S: Analysis of Schistosoma mansoni genes shared with Deuterostomia and with possible roles in host interactions. BMC Genomics 2007, 8:407.

34. Halanych KM: The new view of animal phylogeny. Annual Review of Ecology, Evolution, and Systematics 2004, 35(1):229-256.

35. Aguinaldo AM, Turbeville JM, Linford LS, Rivera MC, Garey JR, Raff RA, Lake $J A$ : Evidence for a clade of nematodes, arthropods and other moulting animals. Nature 1997, 387(6632):489-493.

36. Dunn CW, Hejnol A, Matus DQ, Pang K, Browne WE, Smith SA, Seaver E, Rouse GW, Obst M, Edgecombe GD, Sorensen MV, Haddock SH, SchmidtRhaesa A, Okusu A, Kristensen RM, Wheeler WC, Martindale MQ, Giribet G: Broad phylogenomic sampling improves resolution of the animal tree of life. Nature 2008, 452(7188):745-749.

37. El-Sayed NMA, Bartholomeu D, Ivens A, Johnston DA, LoVerde PT: Advances in schistosome genomics. Trends in Parasitology 2004, 20(4):154-157.

38. Knight RD, Freeland SJ, Landweber LF: A simple model based on mutation and selection explains trends in codon and amino-acid usage and GC composition within and across genomes. Genome Biol 2001, 2(4):RESEARCH0010.

39. Musto H, Alvarez F, Tort J, Maseda HR: Dinucleotide biases in the platyhelminth Schistosoma mansoni. Int J Parasitol 1994, 24(2):277-283.

40. Copeland CC, Marz M, Rose D, Hertel J, Brindley PJ, Santana CB, Kehr S, Attolini CS, Stadler PF: Homology-based annotation of non-coding RNAs in the genomes of Schistosoma mansoni and Schistosoma japonicum. BMC Genomics 2009, 10:464.

41. Berasain P, Goni F, McGonigle S, Dowd A, Dalton JP, Frangione B, Carmona C: Proteinases secreted by Fasciola hepatica degrade extracellular matrix and basement membrane components. J Parasitol 1997, 83(1):1-5.

42. Berasain P, Carmona C, Frangione B, Dalton JP, Goni F: Fasciola hepatica: parasite-secreted proteinases degrade all human IgG subclasses: determination of the specific cleavage sites and identification of the immunoglobulin fragments produced. Exp Parasitol 2000, 94(2):99-110.

43. Dalton J, Caffrey C, Sajid M, Stack C, Donnelly S, Loukas A, Don T, McKerrow J, Halton DW, Brindley PJ: Proteases in trematode biology. In Parasitic Flatworms: molecular biology, biochemistry, immunology and physiology Edited by: Maule AG, Marks NJ. CAB interantional; 2006.

44. Donnelly S, O'Neill SM, Sekiya M, Mulcahy G, Dalton JP: Thioredoxin peroxidase secreted by Fasciola hepatica induces the alternative activation of macrophages. Infect Immun 2005, 73(1):166-173.

45. Donnelly S, Stack CM, O'Neill SM, Sayed AA, Williams DL, Dalton JP: Helminth 2-Cys peroxiredoxin drives Th2 responses through a mechanism involving alternatively activated macrophages. FASEB 2008, 22(11):4022-4032.

46. Jayaraj R, Piedrafita D, Dynon K, Grams R, Spithill TW, Smooker PM: Vaccination against fasciolosis by a multivalent vaccine of stagespecific antigens. Vet Parasitol 2009, 160(3-4):230-236.

47. Dalton JP, McGonigle S, Rolph TP, Andrews SJ: Induction of protective immunity in cattle against infection with Fasciola hepatica by vaccination with cathepsin $\mathrm{L}$ proteinases and with hemoglobin. Infect Immun 1996, 64(12):5066-5074.

48. Sexton JL, Milner AR, Panaccio M, Waddington J, Wijffels G, Chandler D, Thompson C, Wilson L, Spithill TW, Mitchell GF, et al:: Glutathione Stransferase. Novel vaccine against Fasciola hepatica infection in sheep. J Immunol 1990, 145(11):3905-3910. 
49. Morrison CA, Colin T, Sexton JL, Bowen F, Wicker J, Friedel T, Spithill TW: Protection of cattle against Fasciola hepatica infection by vaccination with glutathione S-transferase. Vaccine 1996, 14(17-18):1603-1612.

50. Tran MH, Pearson MS, Bethony JM, Smyth DJ, Jones MK, Duke M, Don TA, McManus DP, Correa-Oliveira R, Loukas A: Tetraspanins on the surface of Schistosoma mansoni are protective antigens against schistosomiasis. Nat Med 2006, 12(7):835-840.

51. Pacifico LG, Fonseca CT, Chiari L, Oliveira SC: Immunization with Schistosoma mansoni $22.6 \mathrm{kDa}$ antigen induces partial protection against experimental infection in a recombinant protein form but not as DNA vaccine. Immunobiology 2006, 211(1-2):97-104.

52. Murray J, Gregory WF, Gomez-Escobar N, Atmadja AK, Maizels RM: Expression and immune recognition of Brugia malayi VAL-1, a homologue of vespid venom allergens and Ancylostoma secreted proteins. Mol Biochem Parasitol 2001, 118(1):89-96.

53. Bethony JM, Simon G, Diemert DJ, Parenti D, Desrosiers A, Schuck S, Fujiwara R, Santiago H, Hotez PJ: Randomized, placebo-controlled, double-blind trial of the Na-ASP-2 hookworm vaccine in unexposed adults. Vaccine 2008, 26(19):2408-2417.

54. Goud GN, Zhan B, Ghosh K, Loukas A, Hawdon J, Dobardzic A, Deumic V, Liu S, Dobardzic R, Zook BC, Jin Q, Liu Y, Hoffman L, Chung-Debose S, Patel $R$, Mendez S, Hotez PJ: Cloning, yeast expression, isolation, and vaccine testing of recombinant Ancylostoma-secreted protein (ASP)-1 and ASP-2 from Ancylostoma ceylanicum. J Infect Dis 2004, 189(5):919-929.

55. Goud GN, Bottazzi ME, Zhan B, Mendez S, Deumic V, Plieskatt J, Liu S, Wang Y, Bueno L, Fujiwara R, Samuel A, Ahn SY, Solanki M, Asojo OA Wang J, Bethony JM, Loukas A, Roy M, Hotez PJ: Expression of the Necator americanus hookworm larval antigen Na-ASP-2 in Pichia pastoris and purification of the recombinant protein for use in human clinical trials. Vaccine 2005, 23(39):4754-4764.

56. Harmsen MM, Cornelissen JB, Buijs HE, Boersma WJ, Jeurissen SH, van Milligen FJ: Identification of a novel Fasciola hepatica cathepsin L protease containing protective epitopes within the propeptide. Int $J$ Parasitol 2004, 34(6):675-682.

57. Meemon K, Grams R, Vichasri-Grams S, Hofmann A, Korge G, Viyanant V, Upatham ES, Habe S, Sobhon P: Molecular cloning and analysis of stage and tissue-specific expression of cathepsin B encoding genes from Fasciola gigantica. Mol Biochem Parasitol 2004, 136(1):1-10.

58. Tkalcevic J, Brandon MR, Meeusen EN: Fasciola hepatica: rapid switching of stage-specific antigen expression after infection. Parasite Immunol 1996, 18(3):139-147.

59. van Milligen FJ, Cornelissen JB, Bokhout BA: Fasciola hepatica: an antigen fraction derived from newly excysted juveniles, containing an immunoreactive $32-\mathrm{kDa}$ protein, induces strong protective immunity in rats. Exp Parasito/ 2000, 94(3):163-171

60. Wilson LR, Good RT, Panaccio M, Wijffels GL, Sandeman RM, Spithill TW: Fasciola hepatica: characterization and cloning of the major cathepsin $B$ protease secreted by newly excysted juvenile liver fluke. Exp Parasitol 1998, 88(2):85-94

61. Corvo I, Cancela M, Cappetta M, Pi-Denis N, Tort JF, Roche L: The major cathepsin $L$ secreted by the invasive juvenile Fasciola hepatica prefers proline in the S2 subsite and can cleave collagen. Mol Biochem Parasitol 2009, 167(1):41-47.

62. Beckham SA, Piedrafita D, Phillips Cl, Samarawickrema N, Law RH, Smooker PM, Quinsey NS, Irving JA, Greenwood D, Verhelst SH, Bogyo M, Turk B, Coetzer TH, Wijeyewickrema LC, Spithill TW, Pike RN: A major cathepsin B protease from the liver fluke Fasciola hepatica has atypical active site features and a potential role in the digestive tract of newly excysted juvenile parasites. Int J Biochem Cell Biol 2009, 41(7):1601-1612.

63. Brindley PJ, Kalinna BH, Dalton JP, Day SR, Wong JY, Smythe ML, McManus DP: Proteolytic degradation of host hemoglobin by schistosomes. Mol Biochem Parasitol 1997, 89(1):1-9.

64. Sajid M, McKerrow JH, Hansell E, Mathieu MA, Lucas KD, Hsieh I, Greenbaum D, Bogyo M, Salter JP, Lim KC, Franklin C, Kim JH, Caffrey CR: Functional expression and characterization of Schistosoma mansoni cathepsin B and its trans-activation by an endogenous asparaginyl endopeptidase. Mol Biochem Parasitol 2003, 131(1):65-75.

65. Delcroix M, Sajid M, Caffrey CR, Lim KC, Dvorak J, Hsieh I, Bahgat M, Dissous C, McKerrow JH: A multienzyme network functions in intestinal protein digestion by a platyhelminth parasite. J Biol Chem 2006, 281(51):39316-39329.
66. Dalton JP, Brindley PJ, Donnelly S, Robinson MW: The enigmatic asparaginyl endopeptidase of helminth parasites. Trends Parasito/ 2009, 25(2):59-61.

67. Krautz-Peterson G, Skelly PJ: Schistosome asparaginyl endopeptidase (legumain) is not essential for cathepsin B1 activation in vivo. $\mathrm{Mol}$ Biochem Parasitol 2008, 159(1):54-58.

68. Gregory WF, Maizels RM: Cystatins from filarial parasites: evolution, adaptation and function in the host-parasite relationship. Int J Biochem Cell Biol 2008, 40(6-7):1389-1398.

69. Schierack P, Lucius R, Sonnenburg B, Schilling K, Hartmann S: Parasitespecific immunomodulatory functions of filarial cystatin. Infect Immun 2003, 71(5):2422-2429.

70. Maizels RM, Gomez-Escobar N, Gregory WF, Murray J, Zang X: Immune evasion genes from filarial nematodes. Int J Parasitol 2001 31(9):889-898.

71. Manoury B, Gregory WF, Maizels RM, Watts C: Bm-CPI-2, a cystatin homolog secreted by the filarial parasite Brugia malayi, inhibits class II MHC-restricted antigen processing. Curr Biol 2001, 11(6):447-451.

72. Cervi L, Rossi G, Masih DT: Potential role for excretory-secretory forms of glutathione-S-transferase (GST) in Fasciola hepatica. Parasitology 1999, 119(Pt 6):627-633

73. Salinas G, Selkirk ME, Chalar C, Maizels RM, Fernandez C: Linked thioredoxin-glutathione systems in platyhelminths. Trends Parasitol 2004, 20(7):340-346

74. McGonigle S, Curley GP, Dalton JP: Cloning of peroxiredoxin, a nove antioxidant enzyme, from the helminth parasite Fasciola hepatica. Parasitology 1997, 115(Pt 1):101-104

75. El Ridi R, Tallima H: Schistosoma mansoni ex vivo lung-stage larvae excretory-secretory antigens as vaccine candidates against schistosomiasis. Vaccine 2009, 27(5):666-673.

76. Geldhof P, Visser A, Clark D, Saunders G, Britton C, Gilleard J, Berriman M, Knox D: RNA interference in parasitic helminths: current situation, potential pitfalls and future prospects. Parasitology 2007, 134(Pt 5):609-619.

77. Rinaldi G, Morales ME, Cancela M, Castillo E, Brindley PJ, Tort JF: Development of Functional Genomic Tools in Trematodes: RNA Interference and Luciferase Reporter Gene Activity in Fasciola hepatica. PLoS Negl Trop Dis 2008, 2(7):e260.

78. McGonigle L, Mousley A, Marks NJ, Brennan GP, Dalton JP, Spithill TW, Day TA, Maule AG: The silencing of cysteine proteases in Fasciola hepatica newly excysted juveniles using RNA interference reduces gut penetration. Int J Parasito/ 2008, 38(2):149-155.

79. Schmid R, Blaxter M: EST processing: from trace to sequence. Methods Mol Biol 2009, 533:189-220.

80. Parkinson J, Guiliano DB, Blaxter M: Making sense of EST sequences by CLOBBing them. BMC Bioinformatics 2002, 3:31.

81. Schmid R, Blaxter ML: annot8r: GO, EC and KEGG annotation of EST datasets. BMC Bioinformatics 2008, 9:180.

82. Bendtsen JD, Nielsen H, von Heijne G, Brunak S: Improved prediction of signal peptides: SignalP 3.0. J Mol Biol 2004, 340(4):783-795.

83. Krogh A, Larsson B, von Heijne G, Sonnhammer EL: Predicting transmembrane protein topology with a hidden Markov model: application to complete genomes. J Mol Biol 2001, 305(3):567-580

84. Rice P, Longden I, Bleasby A: EMBOSS: the European Molecular Biology Open Software Suite. Trends Genet 2000, 16(6):276-277.

85. Mclnerney JO: GCUA: general codon usage analysis. Bioinformatics 1998, 14(4):372-373.

86. Livak KJ, Schmittgen TD: Analysis of relative gene expression data using real-time quantitative PCR and the 2(-Delta Delta $C(T)$ ) Method. Methods 2001, 25(4):402-408.

87. Young ND, Hall RS, Jex AR, Cantacessi C, Gasser RB: Elucidating the transcriptome of Fasciola hepatica - a key to fundamental and biotechnological discoveries for a neglected parasite. Biotechnol Adv 2010, 28(2):222-231

doi: 10.1186/1471-2164-11-227

Cite this article as: Cancela et al., Survey of transcripts expressed by the invasive juvenile stage of the liver fluke Fasciola hepatica BMC Genomics 2010, 11:227 